\title{
Potential and Superior Commodities of Peat Hydrology Area (PHA) of Ogan Komering Ilir Regency South Sumatra (Case Study: PHA Saleh River - Sugihan River)
}

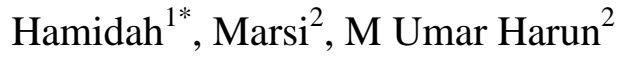 \\ ${ }^{I}$ Magister Student of Environmental Management, Sriwijaya University, Indonesia \\ ${ }^{2}$ Faculty of Agriculture, Sriwijaya University, Palembang, South Sumatra, Indonesia. \\ *Corresponding Author: fennyhamidah@student.pps.unsri.ac.id
}

Article history

\begin{tabular}{llll}
\hline Received & Received in revised form & Accepted & Available online \\
21 December 2019 & 30 March 2020 & 31 March 2020 & 31 March 2020 \\
\hline
\end{tabular}

\begin{abstract}
Non-timber forest products (NTFPs) are great potential in the forest, one of which is in the Saleh-Sugihan River Peat Hydrology Area (PHA). More optimal utilization of NTFPs is obtained with more diverse types of NTFPs, so it is important to know the diversity and potential of commodities in peatland areas for further development based on NTFPs. The research had been conducted from May to July 2018 in the PHA area of the Saleh-Sugihan Rivers, choosing Pangkalan Lampam District, Ogan Komering Ilir Regency, South Sumatra. Research sites include the villages of Air Rumbai, Deling, Lirik, Pangkalan Lampam, Rambai and Sukaraja. The research method is used by sampling, observation, and interview methods. Determination of selected commodities uses analysis of Non-Timber Forest Products / NTFPs (Regulation of the Minister of Forestry of the Republic of Indonesia, 2009). Based on the results of the research that has been carried out, it is concluded that the leading commodity from the Peat Hydrology Area is swallowed, paddy, and fish, while the main commodity in Pangkalan Lampam sub-district is buffalo and purun. Leading commodity types of swallow, paddy, fish become NTFPs that are prioritized to be developed at the PHA River Saleh-Sugihan location, so that their development will be more focused and directed, in order to improve the regional economy.
\end{abstract}

Keywords: NTFPs, PHA Saleh-Sugihan rivers, peatlands

Abstrak: Hasil hutan bukan kayu (HHBK) merupakan potensi besar yang ada di dalam hutan salah satunya di Kawasan Hidrologi Gambut (KHG) Sungai Saleh-Sugihan. Pemanfaatan HHBK yang lebih optimal didapatkan dengan jenis HHBK yang lebih beragam, sehingga perlu diketahui keragaman dan potensi komoditi di areal lahan gambut untuk dikembangkan lebih lanjut yang berbasis HHBK. Penelitian ini dilaksanakan sejak Mei sampai Juli 2018 di kawasan KHG Sungai Saleh-Sungai Sugihan, dengan memilih Kecamatan Pangkalan Lampam, Kabupaten Ogan Komering Ilir, Sumatera Selatan. Lokasi Penelitian mencakup desa Air Rumbai, Deling, Lirik, Pangkalan Lampam, Rambai dan Sukaraja. Penelitian ini menggunakan metode sampling, observasi dan wawancara. Penentuan komoditi terpilih menggunakan analisis Hasil Hutan Bukan Kayu/HHBK (Regulation of the Minister of Forestry of the Republic of Indonesia, 2009). Berdasarkan hasil penelitian disimpulkan bahwa komoditi unggulan Kawasan Hidrologi Gambut yaitu komoditi walet, padi dan ikan, sedangkan komoditi unggulan kecamatan Pangkalan Lampam yaitu komoditi kerbau dan purun. Jenis unggulan komoditi walet, padi dan ikan menjadi jenis HHBK yang lebih diprioritaskan untuk dikembangkan di lokasi KHG Sungai Saleh-Sugihan, sehingga secara selektif pengembangannya akan lebih fokus dan terarah, demi meningkatkan ekonomi daerah.

Kata kunci : HHBK, KHG Sungai Saleh-Sugihan, Lahan Gambut

\section{Introduction}

Indonesia has peatlands on three large islands, namely Kalimantan, Papua, and Sumatra, which reach 14.9 million hectares (Ritung et al., 2011). About 30\% of the peatlands have been used as agricultural land. Moreover, peat is useful for production, water storage, biodiversity habitat, protective functions, and economic functions (Agus et al., 2016). South Sumatra has a peat area of about 1.42 million hectares or about $15.46 \%$ of that in South Sumatra. South Sumatra is the second largest province on the island of Sumatra (after Riau Province), which has a peat area. Peat thickness in South Sumatra
Province varies between $50-400 \mathrm{~cm}$ or included in the shallow a deep category, with around $96.8 \%$ including shallow to moderate peat, the remaining $3.2 \%$ or 45,009 ha is deep peat. Peatland in South Sumatra Province is distributed in Musi Banyuasin Regency, regency Banyuasin, Muara Enim regency, and Ogan Komering Ilir regency (Bappeda, South Sumatra Province, 2014). Peatlands in South Sumatra Province are used for agriculture, fisheries, and farming activities. Community activities on peatlands are often called sonor, lebung, and grazing (Ellyn et al., 2017). In line with economic 
interests and limited land, peatlands have been further exploited as agricultural and plantation areas. The negative impact of changes in land use in the form of peat drought and the threat of fire (Suwondo et al., 2010). Poor control of peatland utilization is certainly a serious threat to hydrology, ecosystems and the economy.

Peatland fires are not only bad for humans, it also has a very bad impact on flora and fauna of the fire area because it can cause carrying capacity and capacity to be reduced, besides peat forest fires resulting in reduced diversity of flora and fauna species. Changes in the peatland area in Sumatra due to fire and land conversion are classified as very large. Wahyunto et al. (2013), from 2004 to 2011, peatlands have decreased by $10.7 \%$ or 783,000 ha. Economic interest factors play a role in reducing the area of peatlands in South Sumatra. The existence of the remaining peatlands is important in restoring peat effectively and sustainably. The activity of restoring peat is a strategic effort, especially for the development of economic commodities that support community income (Susanto, 2014).

Peatlands in the Peat Hydrology Area (PHA) have long been a source of income or the livelihoods. The community is very interested in local commodities on peatlands. One of the intensive PHA has changed its natural function into the location of plantations and food crop agriculture, namely the PHA Saleh-Sugihan River. To find out the factual function of the potential and diversity of peatland, it can be seen from non-timber

\section{Method and Material}

\subsection{Study Area}

The research had been conducted from May to July 2018 in the PHA area of the Saleh-Sugihan River of Pangkalan forest products (NTFPs). Non-timber forest products are great potential in the forest and need to be managed sustainably. The very high potential of NTFPs can greatly assist the community in diversifying income and improving the economic level of the community (Nono et al., 2017). Distribution and abundance of NTFP plant species were determined by ecosystem type (Ehlers et al., 2003). Many factors cause non-optimal utilization of NTFPs, namely neglect of non-timber forest products compared to timber forest products, lack of community knowledge, incomplete information on the potential of NTFPs, and unavailability of facilities and infrastructure for its management. However, NTFPs have serious consequences if resources are over-exploited and conflicts occur in the community (Ehlers et al., 2003).

The utilization of non-timber forest products (NTFPs) has advantages over timber forest products. One of the advantages of NTFPs is that they do not cause greater damage to forests compared to timber utilization, so NTFPs have greater prospects for sustainable development. The management of NTFP species must be based on the potential of these NTFPs and current demand (Ehlers et al., 2003). More optimal utilization of NTFPs is obtained with more diverse types of NTFPs so that more products can be marketed (Indrasari et al., 2017). Therefore, this study aimed to know the diversity and potential of commodities in the peatland area to be further developed based on its NTFPs.

Lampam district, Ogan Komering Ilir regency, South Sumatra. Research sites included the villages of Air Rumbai, Deling, Lirik, Pangkalan Lampam, Rambai and Sukaraja.

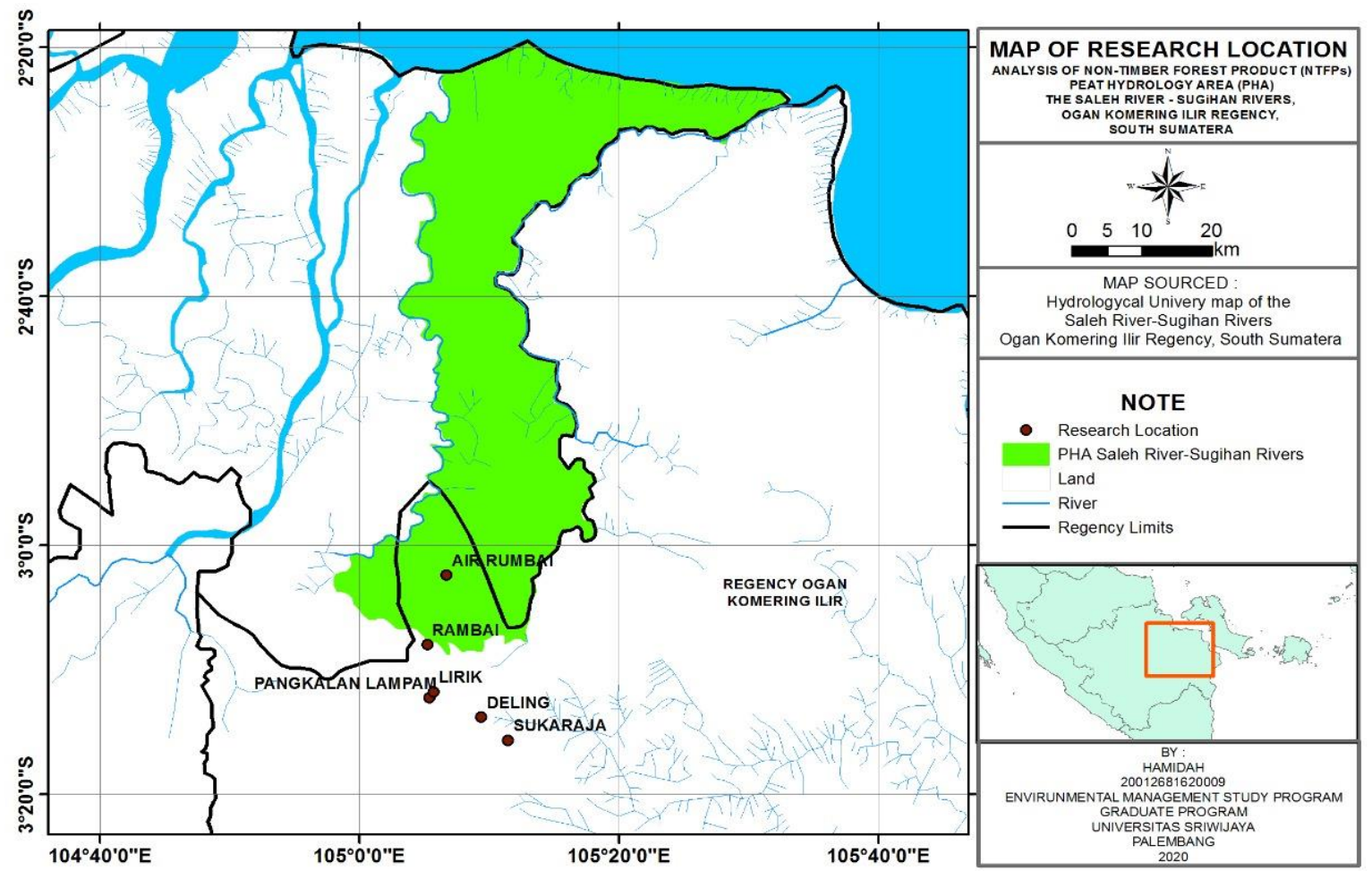


Figure 1. Map of Peat Hydrology Area in Saleh River-Sugihan River at Rumbai village $\left(-3^{\circ} 2{ }^{\prime} 24^{\prime \prime} \mathrm{S} 105^{\circ} 6^{\prime} 42^{\prime \prime} \mathrm{E}\right)$, Deling village $\left(-3^{\circ} 13^{\prime} 48^{\prime \prime} \mathrm{S} 105^{\circ} 9^{\prime} 22^{\prime \prime} \mathrm{E}\right)$, Pangkalan Lampam village $\left(-3^{\circ} 12^{\prime} 15^{\prime}\right.$ S $105^{\circ} 5^{\prime} 24^{\prime}$ ' E), Lirik village

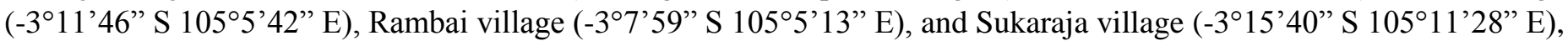
Ogan Komering Ilir Regency, South Sumatra.

2.2

Procedur

es

\subsubsection{Sampling}

Sampling uses purposive sampling with three stages of sampling, namely the selection of subdistricts and sample villages, determination of peat forest location based on commodity, and determination of respondents to be interviewed. The sampling locations are determined based on the main livelihoods of the population, for example, clusters of sub-districts and villages with the main livelihoods of forest products (purun), food agriculture (paddy), livestock (swamp buffalo), fisheries (aquaculture, capture and ponds). Six sample respondents were selected from each village to be interviewed (stratified random sampling) based on the type of business, business volume and business location. Each selected village was visited to see the location of existing or dominant local commodities (Dirawan et al. 2018).

\subsubsection{Observation}

Field observations were carried out on selected villages in order to collect research data. Data collection was performed using the interview method to determine the potential of the research location. To support the data, photos of research sites are also documented. Site surveys conducted in selected villages in order to carry out commodity surveys include 1. Animal husbandry commodities (determining the location and population of Swamp Buffalo, and swamp buffalo breeders visited); 2 . fisheries commodities (determining catching fishers, fish farmers, fish collectors, location of fishponds, and fish populations); 3. swallow commodity (determine the number of swallow nest housing units and estimated production); 4. paddy commodity (determining field agriculture instructors, farmers, locations, and ex-sonor production area); 5. forest commodities (determine the extent of purun, location, area, and purun production); 6. exotic animal and plant commodities and local wisdom of the local community. Information is obtained through community leaders and people who live in peatland areas (Dirawan et al. 2018).

\subsubsection{Analysis and Data Processing}

The data obtained in this study were processed and analyzed descriptively using M.Excel 2016. To determine the selected commodity, an analysis of Non-Timber Forest Products (NTFP) (Permenhut P21, 2009) was conducted. The procedures used to determine the potential and leading commodities of PHA are as follows: a. NTFPs Data Processing

The processing and analysis of quantitative data collected from the field are carried out using the Non-Parametric Statistical method (description scoring). Mathematically, the calculation is done with the following formula:

$$
\mathrm{WIV}_{c}=\frac{\mathrm{W}_{k}}{\mathrm{NI}_{k}}\left(\sum_{i=1}^{n} \frac{\mathrm{Vi}}{\mathrm{Vi}_{\max }}\right)
$$

$\begin{array}{ll}\text { Whereas : } \\ \text { WIV } & =\text { Weighted Indicator Value } \\ \mathrm{c} & =\text { Criteria for determining the winner }(1-5) \\ \mathrm{n} & =\text { Number of indicators in each criterion } \\ \mathrm{Vi} & =\text { Indicator values for each criterion } \\ \text { Wk } & =\text { The value of the weight of the criteria to } \mathrm{k} \\ \text { Vimax } & =\text { The biggest indicator value, in this case } 3 \\ \text { NIk } & =\text { Number of indicators of the criteria to } \mathrm{k}\end{array}$

b. Determination of Total Superior Value (TSV) Calculation of Total Superior Value (TSV) of a type of NTFPs is done by summing up all the weighted indicator values of all criteria.

TSV = economic WIV + Biophysical WIV + Institutional WIV + Social WIV + Technology WIV

According to P.21 / Menhut-II / 2009, the Determination of Superior Values, based on the Total Superior Value (TNU) of NTFPs, is grouped into three classes of Superior Value (SV) as follows:

1. Superior Values 1. Types of NTFP commodities that have TSV values between 78-100

2. Superior Values 2. Types of NTFP commodities that have TSV values between $54-77$

3. Superior Values 3. Types of NTFP commodities that have TSV values between $30-53$

Determination of the superiority of NTFP types is determined by 5 (five) criteria, where each criterion has a different weight, and the magnitude of the weight indicates the level of the role of a criterion compared to other criteria in determining the superiority of NTFP types being evaluated. Determination of importance is measured by weighting expressed in terms of role percentages. The higher the weight value indicates the more important role of criteria in determining the level of superiority of NTFPs, and vice versa. By the level of role, the 
weight criteria are set at $35 \%$ for economic aspects, $15 \%$ for physical and environmental aspects, $20 \%$ for institutional aspects, $15 \%$ for social aspects, and $15 \%$ for technical aspects. The total weight is $100 \%$.

\section{c. Determination of the Types of Superior NTFPs}

According to P.21 / Menhut-II / 2009 (modification), the Determination of Types of Superior NTFPs is carried out based on the size of the Superior Value scores and considers the frequency of distribution of commodity types in an area. Furthermore, the types of Superior NTFPs are grouped into four classes; NTFPs Superior PHA/ NTFPs Superior District, NTFPs Superior Village, and Non-Superior NTFPs. Determination as follows:

1. NTFPs Superior HPA is a type of NTFPs that are included in SV 1 and is spread out at least in five districts.

2. NTFPs Superior District is a type of NTFPs included in SV 1 that is spread out in less than 5 villages and SV 2 in at least 2 locations.

3. NTFPs Superior Sub-district is a type of NTFPs commodity that is included in at least SV 2.

4. Non-Superior NTFPs is the type of NTFPs commodities included in SV 3.

Determination of types of superior NTFPs is an evaluation phase of all types of NTFPs that will be determined to be superior types at a location. Superior type is a type of NTFP that is a priority to be developed at the site so that its development will be more selectively focused and directed.

The criteria chosen to determine the level of superior of NTFPs include economic, biophysical and environmental, institutional, social, and technological criteria. From each criteria, several indicators can be measured in quantitative and qualitative values and expressed as standards. The measurement in the standard is then given a value, where the value reflects the ranking of the facts of the condition or situation of the indicators in the area. The higher the score (score) indicates, the better level of NTFPs to be determined as a superior type.

\section{Result and Discussion}

\subsection{General Conditions and Land Use in Pangkalan Lampam District}

The Saleh river-Sugihan river PHA covers areas in Banyuasin Regency (Muara Sugihan District, Muara Padang, Air Kumbang), and in OKI regency (Pangkalan Lampam district). In the PHA Saleh River and Sugihan River, there are various villages bordering the forest area and having creeks originating from peat forests. Based on the results of interviews with community leaders in the Districts of Muara Sugihan, Muara Padang and Air Kumbang, it is known that there are six villages that utilize various commodities from the PHA Saleh River-Sugihan River. Meanwhile, In Pangkalan Lampam Subdistrict, OKI Regency, there are six villages located in the PHA. The villages in Pangkalan Lampam Subdistrict selected as samples are Air Rumbai, Rambai, Lirik, Pangkalan Lampam, Deling and Sukaraja. Based on the results of the survey in the field, there are potential peatland commodities to be developed in order to increase the economic value of the community, such as swallow, paddy, purun, fish, swamp buffalo. The majority of the people earn a living as farmers and swallow breeders, buffalo breeders, purun craftsmen, and fish catchers.

A minority of the people of Pangkalan Lampam sub-district are still doing sonor paddy cultivation. Most of the ex-sonor paddy fields in the Pangkalan Lampam sub-district have not been converted into permanent paddy fields. Swamp buffalo breeders generally manage both their own and those from government donations to improve their economy. Fish commodities in the Pangkalan Lampam sub-district consist of gabus, betok, sepat, and sapil fish. Based on their experience, purun craftsmen in the Pangkalan Lampam sub-district have local knowledge in choosing purun for plaiting. To maintain the quality of matting, they only use purun, which has a height of at least 2-2.5 m. The community increases the value of purun by utilizing purun as raw material for woven mats, bags, hats, and others.

The general condition of peatlands in the Pangkalan Lampam sub-district has characteristics of peat that is prone to burning during the dry season, and experiences flooding during the rainy season. The villages in the Pangkalan Lampam sub-district have different levels of peat depth. Each peat depth is overgrown by different vegetation, in the depths of shallow peat and moderate vegetation that grows are the kelakai fern (Stenochlaena palustris), the purun tikus (Eleocharis dulcis), and the Senduduk (Melanstoma malabathricum). The majority of these plants grow mostly on medium and deep peat, the eucalyptus/cajuput (Melaleuca cajuputi), the belidang (Scleria terrestris), and the pulai or white cheese wood (Alstonia spatulate Blume) often grow on shallow and moderate peat. Animals that are often found on the mainland peatlands such as, deer (Cervidae), python (Pythonidae), and water monitor lizards (Varanus salvator), whereas in peat waters are often found crocodiles (Crocodylus porosus), the tapa fish or fresh water shark (Wallago attu), the putak fish or featherback fish (Notopterus notopterus), the snakehead fish (Channa striata), the betok fish or climbing perch (Anabas testudineus), and others. The method used to identify flora and fauna in this study is based on the information obtained in the results of the interviews that have been conducted then matched to plantamor identification (www.plantamor.com) 


\subsection{Commodity Performance in the Saleh River- Sugihan River Peat Hydrological Area}

Based on the results of a survey on paddy commodity, it turns out that paddy fields in the Pangkalan Lampam sub-district area have not been changed to permanent fields so that the productivity of paddy fields is still not optimal. While the results of the survey on fish commodities, villages that are fish producers are Deling and Pangkalan Lampam, while other villages have not recorded how much fish is produced. The types of fish that are mostly produced from Ogan Komering Ilir regency include lampam fish (Barbonymus schwanenfeldii), the jambal fish (Pangasius djambal), the snakehead fish (Channa striata), the lais fish (Kryptopterus bicirrhis), the toman fish (Channa micropeltes), the sepat siam fish (Trichopodus pectoralis), the tambakan fish (Helostoma temminckii), the belida fish (Chitala), the betutu fish (Oxyeleotris marmorata), galadah shrimp (Macrobrachiym rosenbergii), blackhead fish
(Leptobarbus hoevenii), and catfish (Clarias). The fish are caught from canals in peatlands and from community aquaculture ponds.

Based on the survey results, small-scale industries and household handicrafts in Lampam's Pangkalan sub-district are dominated by purun woven. In the livestock sector, buffalo commodity has prospects to be developed because of the high demand for products of around \pm 40 animals/year. In the livestock sector there is also a swallow commodity currently cultivates many birds' nests, most of the people's house has a swiftlet farm, about $60 \%$ of people have cattle swallow. Animal husbandry provides a high enough profit and is a source of income for the community and is one of the spearheads of development. This is an effort to explore all the potential of existing natural resources and utilize them optimally for the benefit of the development and welfare of the people of OKI Regency (Table 1).

Table 1. Performance of Potential Commodities in PHA Saleh River - Sugihan River Ogan Komering Ilir Regency

\begin{tabular}{|c|c|c|c|c|c|c|c|c|}
\hline \multirow[t]{2}{*}{ Commodity } & & \multicolumn{6}{|c|}{ Village } & \multirow[b]{2}{*}{ Mean } \\
\hline & & $\begin{array}{c}\text { Air } \\
\text { Rumbai }\end{array}$ & Deling & Lirik & Rambai & $\begin{array}{c}\text { Pangkalan } \\
\text { Lampam }\end{array}$ & Sukaraja & \\
\hline \multirow{3}{*}{ Paddy } & Area (ha) & 300 & 0 & 110 & 650 & 150 & 500 & 1710 \\
\hline & $\begin{array}{l}\text { Production (Tons } \\
\text { DGC/year) }\end{array}$ & 600 & 0 & 250 & 1300 & 300 & 1000 & 3450 \\
\hline & $\begin{array}{l}\text { Productivity } \\
\text { (Tons } \\
\text { DGC/ha/year) }\end{array}$ & 2 & 0 & 2.28 & 2 & 2 & 2 & 10.28 \\
\hline Fish & $\begin{array}{l}\begin{array}{l}\text { Production } \\
\text { (Tons/year) }\end{array} \\
\end{array}$ & $\mathrm{x}$ & 100 & $\mathrm{x}$ & $\mathrm{x}$ & 30 & $\mathrm{x}$ & 130 \\
\hline \multirow{3}{*}{ Purun } & Area $(\mathrm{Ha})$ & 20 & 200 & 0 & 0 & 50 & 0 & 270 \\
\hline & $\begin{array}{l}\text { Production } \\
\text { (Bundle/year) }\end{array}$ & 4000 & 40000 & 0 & 0 & 5000 & 0 & 49000 \\
\hline & $\begin{array}{l}\text { Productivity } \\
\text { (Bundle/ha/year) }\end{array}$ & 200 & 200 & 0 & 0 & 100 & 0 & 500 \\
\hline Buffalo & Total & 30 & 206 & 25 & 27 & 200 & 0 & 488 \\
\hline \multirow{3}{*}{ Swallow } & nest (Unit) & 15 & 100 & 12 & 21 & 30 & 0 & 178 \\
\hline & $\begin{array}{l}\text { Production } \\
\text { (Kg/year) }\end{array}$ & 2 & 12 & 1 & 2 & 2 & 0 & 19 \\
\hline & $\begin{array}{l}\text { Productivity } \\
\text { (Kg/unit/year) }\end{array}$ & 0.133 & 0.12 & 0.83 & 0.09 & 0.07 & 0 & 1.18 \\
\hline
\end{tabular}

Note: $\mathrm{x}$ (not record), DGC (dry grain crop)

Based on Table 1, it can be seen that the paddy commodity in the six villages has different performance, land area, and production value, which is relatively similar, which is only in productivity. Paddy fields in the village of Rambai are among the villages that produce the most harvested unhusked paddy (DGC) per year; this is because the village has a large enough land that is used by the community to produce paddy. This is inversely proportional to the village of Deling. In Deling village, the land is difficult to use for paddy cultivation because most of the village area is a peatland. The swamps in Deling village are used by most villagers as a place to produce purun, to catch fish, and to graze buffalo.

The performance of the value of fish commodities in various PHA villages in the Saleh-
Sugihan River is largely unrecorded (Table 1). Fish production is only Recorded at the villages of Deling and Pangkalan Lampam; this is because in both villages there are lebak lebung (the deepest part of the basin of the fresh-water swamp) which is rich in fish and usually during the dry season is auctioned for fish to be harvested so that the results of the fish are recorded. Lebak Lebung is used by the community to meet basic needs and increase economic value. Whereas in the villages of Air Rumbai, Lirik, Rambai, and Sukaraja, fish production was not recorded. This is because they are looking for fish just to fill their free time when there is no activity. Usually, the villagers look for fish in the canals or the swamps in the village. 
Purun commodities are produced in the villages of Deling, Air Rambai, and Pangkalan Lampam. This is because the condition of the swamps in the three villages is inundated throughout the year or in quite a long time in a year. This swamp condition is a natural habitat for the growth of purun vegetation. Purun is generally used by local people as plaited to make bags, mats, hats, and others. Purun production in Air Rumbai village is lower than the other two villages. This is because the purun habitat is narrower, and the condition of the swamp is not always flooded. In addition to utilizing purun, the Air Rumbai community uses more land for the agricultural sector. Of the six villages surveyed, there were three villages that did not produce purun because the land was deep peat swamps.

The highest number of buffalo commodities is in the Riding village. This is because in Riding village, there are stretches of flooded land, especially in the rainy season, and in the dry season some lands are still flooded. Such environmental conditions are very supportive of buffalo cattle and buffalo breeding. In other villages, only a few communities owned and raised buffalo, and most of the buffaloes were housed and released only around the cage. Nobody in the village of Sukaraja has raised buffalo.

Swallow houses and swallow production are mostly found in the village of Deling. This is because the majority of people own and develop swallow houses. The location of swallow houses belonging to the Deling village community is generally located around the paddy fields and near the purun land. It aims to make swiftlets easier to get food. Local wisdom of the community believes that if the swallow's house is placed near paddy fields or swamp inundated, the swallow will be more productive. Furthermore, the total swallow production in each village of Pangkalan Lampam, Rambai, Air Rumbai is almost the same as swallow production in Deling village, but the number of swallow houses found in each village is far greater. Whereas in the village of Lirik, the community only has a few swallow housing units. This is because the economic level of most of the community is still low, so it is not yet able to build swallow houses. In all villages, the majority of people use their residential buildings to function as swallow houses. Whereas in the village of Sukaraja, there are some communities that have a desire to build swallow houses around their home area. The more swifts found in a swallow's house, the more productive it will be.

Based on the results of research conducted in the six villages, it can be seen that the village with the best economic level is Pangkalan Lampam. This is because the village of Pangkalan Lampam has local wisdom and the most productive land for various commodities cultivated in the agriculture, fisheries, and livestock sectors whereas the land in the villages of Air Rumbai, Deling, Lirik, and Rambai was only cultivated for several commodities with lower productivity levels. Whereas in the village of Sukaraja, the land used was only cultivated for paddy. Sukaraja village is one of the villages that is difficult to reach, due to inadequate road access and can only be passed by two-wheeled vehicles. Sukaraja village is also a village with a low economic level and should receive more attention from the local government.

\subsection{Commodity Superior Potential in PHA Saleh River-Sugihan River}

Based on the analysis of the data obtained, it turns out that the Weighted Index Value (WIV) of the five commodities is relatively high. The highest economic category WIV is swallowed commodity with a value of 32.50, and the lowest is a buffalo commodity with a value of 15.00. As for Biophysical and Environmental WIV, the highest WIV is paddy with a value of 19.75, and the lowest is purun with a value of 8.00. For the WIV Institutional category, the highest WIV was obtained for paddy with a value of 16.94, and the lowest was purun with a value of 3.33. Whereas in the Social WIV category, the highest WIV is fish, buffalo, paddy, which has the same value of 25.00 , while the lowest is purun and swallow with a value of 15.00. For WIV in the Technology category, the highest WIV is purun and swallow with a value of 15.00 , while the lowest is fish, buffalo, paddy with a value of 5.00 (Table 2 ).

Table 2. Potential Value of Potential Local Commodities in PHA Saleh River - Sugihan River

\begin{tabular}{lccccc}
\hline \multirow{2}{*}{ Commodity } & \multicolumn{5}{c}{ Weighted Index Value (WIV) } \\
\cline { 2 - 6 } & WIV 1 & WIV 2 & WIV 3 & WIV 4 & WIV 5 \\
\hline Fish & 29.17 & 13.25 & 11.67 & $\mathbf{2 5 . 0 0}$ & 5.00 \\
Buffalo & 15.00 & 16.50 & 5.00 & $\mathbf{2 5 . 0 0}$ & 5.00 \\
Paddy & 25.00 & $\mathbf{1 9 . 7 5}$ & $\mathbf{1 6 . 9 4}$ & $\mathbf{2 5 . 0 0}$ & 5.00 \\
Purun & 22.50 & 8.00 & 3.33 & 15.00 & $\mathbf{1 5 . 0 0}$ \\
Swallow & $\mathbf{3 2 . 5 0}$ & $\mathbf{1 9 . 7 5}$ & 13.61 & 15.00 & $\mathbf{1 5 . 0 0}$ \\
\hline
\end{tabular}

WIV 1: Weighted Index Value of Economic Category

WIV 2: Weighted Index Values of Biophysical and Environmental Categories

WIV 3: Institutional Weighted Index Values

WIV 4: Weighted Index Value Social Category

WIV 5: Weighted Index Value of Technology Category 
WIV Economic category is highest in swallow commodities. This is because most villagers have swallow houses that are already in production. Most villagers are interested in building swallow houses because the building is simple and not too difficult to maintain. Also, the swallow nest has a very expensive selling price high yield and is in demand by national and international markets. Some factors that affect WIV swallow are higher than other commodities, namely the location or distance between the forest and the location of residence, land area, and market prices (Nono et al. 2017; Indrasari et al. 2017). This is what causes swallow as a commodity sector that can properly increase the economic value of the district or the local village community.

While the lowest Economic Category WIV is found in buffalo commodities, this is because not all villages have buffalo cattle and the lack of community knowledge about how to properly manage buffalo to meet economic needs. People only breed buffalo commodities without being processed to become derivative products. The utilization of buffalo commodity has not been well developed in terms of technical aspects due to the lack of socialization from related agencies and the background of the village community itself. This has caused the Economic WIV of buffalo to be very low in the OKI district.

The highest biophysical and environmental categories are found in paddy and Swallow commodities. This is because the ecosystem in the area is suitable for the development of paddy and swallow commodities. Appropriate use and management of land for paddy and swallow commodities do not damage the environment, and available land is suitable for the development of these commodities. The land used for swallow does not cause environmental pollution, while the management of paddy plants does not use materials that damage the biophysical and environmental aspects. As for the biophysical and environmental categories of WIV, the lowest WIV was found in purun. This is because many purun ecosystems switch functions to other plant ecosystems that have better economic value. Besides that, people's interest in using purun as an economic resource is still low due to their low selling power. Most of the areas of the tidal swamp and peat swamp areas are overgrown by purun. This plant makes it difficult for other vegetation to grow and develop.
Based on the institutional category aspect, the highest institutional WIV is found in paddy commodities. This is because paddy is a basic and primary need of the community, as well as national food commodities. Paddy commodity has official regulations. Also the local government has its authority in managing paddy commodities, and there is a special group of farmers in paddy commodities in the OKI district whereas the WIV was the lowest Institutional category, namely the purun commodity. This is due to the absence of local government regulations that regulate and pay attention to the existence, development and use of the purun. Purun is only the creativity of the hands, and local wisdom for the people of the OKI district.

In the WIV Social category, the highest WIV is in fish, buffalo, and paddy. This is because the commodity has been cultivated throughout time so that it has become a daily habit that has been passed down from generation to generation and has become local wisdom in the community environment. In each village, these commodities were found whereas the lowest WIV for the Social category is purun and swallow. This is due to 1 . lack of public knowledge about management, benefits, and interests of the community to develop purun commodities; 2 . Management of purun commodities in the area, including culture not passed down to family members; and 3. reduction in the area of purun commodity. Whereas the swallow commodity is difficult to develop because the community must have sufficient capital to develop the commodity.

Furthermore, for the highest technology category, which is found in purun and swallow commodities, this is due to the processing of purun commodity processing technology, which still uses traditional methods, whereas swallow requires technology in the processing of swallow products. The lowest technology category is in the commodity Fish, Buffalo, paddy; this is because the development of the three commodities in the village does not use technology in management and systems in harvesting yields.

Based on the analysis of the Total Superior Value (TSV) of the five commodities, it can be seen that fish, paddy and swallow are classified as superior commodities of PHA Saleh river-Sugihan river, while buffalo and purun are among the superior commodities of Pangkalan Lampam sub-district (Table 3).

Table 3. Main Commodity in PHA Saleh River-Sugihan River and Pangkalan Lampam District

\begin{tabular}{lccc}
\hline Commodity & Total Superior Value (TSV) & Superior Value (SV) & Note \\
\hline Fish & 84.08 & Superior Value 1 & PHA \\
Buffalo & 66.50 & Superior Value 2 & Sub-District \\
Paddy & 91.69 & Superior Value 1 & PHA \\
Purun & 63.83 & Superior Value 2 & Sub-District \\
Swallow & $\mathbf{9 5 . 8 6}$ & Superior Value 1 & PHA \\
\hline
\end{tabular}


The first highest superior value is found in swallow commodities. This is because the swallow commodity has the highest economic WIV. The community is more concerned with economic aspects compared to other aspects of local economic sustainability and progress. Also, swallow commodities are included in the PHA featured because they are spread in more than five districts. This superior swallow commodity is a type of NTFPs that are prioritized for development at the location. Therefore, selectively developing swallow commodities will be more focused, and focused, in order to improve the regional economy whereas the second-lowest superior value is purun commodity, including the superior district. This is because the purun commodity is spread out in less than five villages or at least two locations.

\section{Conclusion}

Superior commodities from Peat Hydrology Area (PHA) of the Saleh river-Sugihan river are swallowed, paddy and fish. Whereas for superior commodities of Pangkalan Lampam Subdistrict are buffalo, and purun commodities. Therefore, superior commodity types of swallow, paddy, fish become NTFPs that are prioritized to be developed at the PHA Saleh riverSugihan river location so that their development will be more focused and directed, in order to improve the regional economy.

\section{Acknowledgment}

This research was partly sponsored by the Peat Restoration Agency (2017).

\section{References}

Agus F, Anda M, Jamil A, Magnanti. 2016. Indonesian Peatlands: Formation, Characteristics, and Potential. Jakarta (246): IAARD Press.

Bappeda, South Sumatra Province. 2014. Regional Medium-Term Development Plan (RPJMD) of South Sumatra Province in 2013-2018. Provincial Government of South Sumatra.

Dirawan, A., Suranto., and Sunarto. 2018. analysis of leading NTFP commodities in the community forest area of Central Lombok regency. Journal of Tropical Forests. 6(3): 277-286.

Ehlers, T., Berch, M, S., and MacKinnon, A. 2003. Inventory of Non-Timber Forest Product Plant and Fungal Species in the Robson Valley. Bc Journal of Ecosystems and Management. 2(4): 1-15.

Ellyn, K., Damayanti., and L.B. Prasetyo 2017. Biodiversity strategies and action plans in South Sumatra Province (2017-2021). South Sumatra Government Forest Service.

Indrasari, D., Wulandari, C., and Bintoro, W. 2017. The Development Plan of Non-Timber Forest Products Potential by Sadar Hutan Lestari Wana Agung Groups at Register 22 Way Waya Lampung Tengah Regency. Syalfa Journal. 1 (5): 81-91.

Nono., Diba, F., and Fahrizal. 2017. Utilization of Non-Timber Forest Product by Rural Communities in Labian Ira'ang Villages and Data Village in Kapuas Hulu Regency. Journal of Sustainable Forests. 1 (5): 76-87.

Ritung, S., Wahyunto, K. Nugroho, Sukarman, Hikmatullah, Suparto, and C. Tafakresnanto. 2011. Map of Indonesian Peatlands Scale 1: 250,000. Indonesian Center for Agricultural Land Resources. Bogor, Indonesia.

Regulation of the Minister of Forestry of the Republic of Indonesia. 2009, Number: P21 / Menhut II. Concerning Criteria and Indicators for Establishing Government Administration Areas.

Susanto, R.H. 2014. Fire problems and solutions related to agricultural development in swamp/peat areas. Data and Information Center for Swamp and Coastal Areas. PPM. Sriwijaya University, Palembang.

Suwondo, S. Sabihan, Sumardjo, and B. Paramadya. 2010. Analysis of the biotic environment of peatlands on oil palm plantations. Hydrolytic 1 (3): 20-28.

Wahyunto., Dariah, A., Pitono, D., and Muhrizal, S. 2013. The Effects of the Utilization of Peatlands for Oil Palm Plantations in Indonesia. Perspective. 12 (1): 11-22. 